\title{
DINAMIKA DAYA SAING EKSPOR FURNITURE ROTAN INDONESIA KE NEGARA TUJUAN EROPA
}

\author{
Muhammad Fathul Anwar1, Harianto ${ }^{2}$, dan Suharno ${ }^{3}$ \\ 1)Program Studi Agribisnis Fakultas Pertanian, Universitas Veteran Bangun Nusantara Sukoharjo \\ Jl. Letjend Sujono Humardani No. 1 Sukoharjo, Indonesia \\ 2,3)Departemen Agribisnis, Fakultas Ekonomi dan Manajemen, Institut Pertanian Bogor \\ Jl. Kamper Wing 4 Level 5 Kampus IPB Dramaga Bogor, Indonesia \\ e-mail : 1)fathulanwar32@gmail.com
}

(Diterima 10 Juni 2019/Disetujui 27 Juni 2019)

\begin{abstract}
Indonesian rattan was one of the natural commodity which has been traded since long time ago. As one of the natural wealth, rattan has an important role in economic growth for Indonesia. The availability of rattan is abundant in the forests of Indonesia, especially in Kalimantan, Sulawesi and Sumatra, making Indonesia a major supplier of rattan world needs, but the export value of Indonesian rattan furniture in the last few years dropped. This research aims to analyze the competitiveness of Indonesian rattan furniture to the largest European importing countries and the determinant factors affecting the competitiveness of Indonesian rattan furniture. The data used in this study were annual time series data from 2007-2016. The methods used were the competitiveness test with the approach of Revealed Comparative Advantage (RCA) and Revealed Symmetric Comparative Advantage (RSCA) was used to analyze the competitiveness of Indonesian rattan furniture to the European importing countries. The results showed that Indonesia had strong competitiveness in 4 European importing countries, especially the United Kingdom and Italy rattan furniture market that had a higher point of competitiveness with 141.01 \& 100.95 RCA's point respectively. This made both as a major export option of Indonesian rattan furniture in the future.
\end{abstract}

Keywords: competitiveness, indonesian rattan furniture, RCA, RSCA

\begin{abstract}
ABSTRAK
Rotan Indonesia adalah salah satu komoditas alami yang telah diperdagangkan sejak lama. Sebagai salah satu kekayaan alam, rotan memiliki peran penting dalam pertumbuhan ekonomi Indonesia. Ketersediaan rotan sangat banyak di hutan Indonesia, terutama di Kalimantan, Sulawesi dan Sumatra, menjadikan Indonesia pemasok utama kebutuhan dunia rotan, akan tetapi Nilai Ekspor furniture rotan Indonesia dalam beberapa tahun terakhir justru mengalami penurunan. Penelitian ini bertujuan untuk menganalisis daya saing furniture rotan Indonesia ke negara-negara pengimpor Eropa terbesarnya dan juga menganalisis faktor-faktor penentu yang mempengaruhi daya saing furniture rotan Indonesia. Data yang digunakan dalam penelitian ini adalah data deret waktu tahunan yakni dari 2007-2016. Metode yang digunakan dalam penelitian ini yaitu melalui uji daya saing dengan pendekatan Revealed Comparative Advantage (RCA) dan Revealed Symetric Comparative Advantage (RSCA) digunakan untuk menganalisis daya saing furniture rotan Indonesia ke negara-negara importir Eropa. Hasil penelitian menunjukkan bahwa Indonesia memiliki daya saing kuat di 4 negara pengimpor Eropa, terutama di pasar furniture rotan negara Inggris dan Italia yang memiliki daya saing lebih tinggi dibanding pasar lainnya yaitu dengan nilai RCA sebesar 141,01 dan 100,95. Hal tersebut menjadikan keduanya sebagai opsi utama pangsa ekspor furniture rotan Indonesia di masa yang akan datang.
\end{abstract}

Kata kunci: daya saing, furniture rotan indonesia, RCA, RSCA

\section{PENDAHULUAN}

Sebagai negara yang memiliki sumber daya alam yang beragam, Indonesia memiliki peluang serta potensi yang sangat tinggi untuk menciptakan iklim industrialisasi yang baik dengan cara mengembangkan industri yang sudah ada, mulai dari industri hulu ke 
industri hilir hingga ke konsumen akhir. Salah satu sub sektor industri yang memiliki potensi cukup besar untuk dikembangkan di Indonesia serta memiliki pasar yang potensial baik di pasar domestik maupun pasar internasional adalah industri pengolahan rotan. Secara ekonomi, produksi rotan cukup menjanjikan untuk terus dikembangkan dan dapat dijadikan sebagai sumber baru perolehan devisa negara. Indonesia merupakan negeri penghasil rotan mentah terbesar di dunia. Indonesia memiliki keunggulan tersendiri di bidang industri rotan yang mampu menjadikannya sebagai pemain dominan yaitu dengan ketersediaan bahan baku yang melimpah.

Saat ini ketersediaan rotan sangat banyak dan tersebar di berbagai hutan di Indonesia terutama di wilayah Kalimantan, Sulawesi, dan Sumatera dengan jumlah produksi ratarata sebesar 690.000 ton per tahun, dimana berdasarkan data dari UN Comtrade di tahun 2016 ekspor total furniture rotan Indonesia mencapai USD 24.590.836,00 menjadikan Indonesia sebagai pemasok utama kebutuhan rotan dunia dan hampir di setiap tahunnya Indonesia menyumbang sekitar $70 \%$ bahan baku rotan yang ada di dunia untuk diserap oleh industri rotan di berbagai belahan dunia. Hal ini sejalan juga dengan dengan penelitian yang pernah dilakukan oleh Kismandani (2008), dimana kerajinan rotan telah menunjukkan daya saing yang kuat sebagai salah satu komoditas ekspor Indonesia dan dapat dikatakan berdaya saing di pasar internasional. Melalui penelitian dari Hoang $\mathrm{V}$ et al. (2017), Indonesia juga dipandang memiliki daya saing yang kuat dalam hal furniture rotan, dan posisi furniture rotan Indonesia telah berdaya saing dan menjadi salah satu pesaing kuat Vietnam.

Sebagai salah satu kekayaan alam hayati Indonesia, olahan rotan mampu menyumbang devisa terbesar dari hasil hutan non kayu yaitu dengan penerimaan ekspor pada tahun 2012 sebesar USD 286,72 juta, sedangkan hasil hutan non kayu lainnya yaitu minyak atsiri hanya menyumbangkan USD 222,97 juta dan hasil hutan lainnya yang sebesar USD 43,14 juta saja (Kemenperin 2015). Ekspor dari produk hasil hutan sendiri menjadi salah satu dari 10 komoditas ekspor utama di Indonesia. Sejak tahun 2012 sampai tahun 2014 ekspor produk hasil hutan menunjukan peningkatan yang sangat baik. Namun, di tahun 2014 ekspor produk hasil hutan mulai menunjukkan penurunan hingga tahun 2016. Nilai ekspor hasil hutan di tahun 2012 mencapai 8,7 Miliar US\$ dan terus meningkat hingga mencapai 9,2 Miliar US\$ di tahun 2014. Sejak tahun 2014, nilai ekspor produk hasil hutan terus menurun dan di tahun 2016 hanya mencapai 8,54 Miliar US\$.

Penurunan yang terjadi pada total ekspor hasil hutan Indonesia tersebut sejalan pula dengan penurunan besaran ekspor furniture rotan Indonesia di pasar internasional khususnya di tahun-tahun akhir 2015-2016, dimana sebagian besarnya didominasi oleh negara-negara importir dari Eropa diantaranya adalah Jerman, Belanda, Inggris dan Italia. Keempatnegara importir Eropa tersebut tergolong negara importir utama dan memiliki nilai ekspor yang cukup besar diantara antara negara importir lainnya. Adanya penurunan pada nilai ekspor secara tidak langsung juga berpengaruh pada penurunan produksi suatu komoditi. Hal tersebut sesuai dengan hal yang telah diutarakan oleh Boansi et al. (2014) dalam penelitiannya, dimana baik volume maupun nilai ekspor sama-sama memiliki hubungan positif dengan produksi. Apabila harga dan nilai ekspor furniture rotan Indonesia mengalami penurunan, hal yang ditakutkan adalah akan menurunkan juga minat dari para eksportir untuk meningkatkan volume ekspornya, nantinya akan berdampak pada penurunan produksi dari industri furniture rotan Indonesia dan juga daya saingnya.

Tabel 1. menunjukkan bahwa ekspor furniture rotan Indonesia dengan kode HS 940381 ke Eropa di tiap tahunnya cukup berkembang, meskipun dalam tiga tahun terakhir terlihat trend penurunan nilai ekspor mulai terjadi. Belanda, Italia dan Inggris menjadi tiga negara yang cukup konsisten menurun nilai ekspornya di tahun terakhir 
Tabel 1. Nilai Ekspor Furniture Rotan (HS 940381) Indonesia di Negara Importir Eropa tahun 2007-2016

\begin{tabular}{ccrrr}
\hline Tahun & UK & Jerman & Belanda & \multicolumn{1}{c}{ Italia } \\
\hline 2007 & 5.776 .453 & 8.148 .282 & 4.812 .757 & 5.178 .323 \\
2008 & 4.407 .179 & 5.313 .261 & 3.501 .591 & 976.737 \\
2009 & 2.120 .127 & 4.748 .721 & 1.372 .244 & 884.839 \\
2010 & 5.993 .871 & 17.954 .725 & 4.322 .028 & 3.847 .230 \\
2011 & 2.662 .530 & 13.766 .693 & 2.734 .671 & 2.043 .939 \\
2012 & 1.441 .210 & 2.859 .960 & 1.059 .574 & 2.091 .648 \\
2013 & 1.710 .022 & 1.377 .178 & 1.775 .272 & 1.601 .800 \\
2014 & 1.592 .709 & 1.533 .444 & 1.977 .656 & 1.260 .067 \\
2015 & 1.974 .448 & 976.773 & 1.441 .571 & 897.196 \\
2016 & 1.620 .532 & 1.345 .117 & 1.322 .346 & 782.673 \\
\hline Rata-rata & $\mathbf{2 . 9 2 9 . 9 0 8}$ & $\mathbf{5 . 8 0 2 . 4 1 5}$ & $\mathbf{2 . 4 3 1 . 9 7 1}$ & $\mathbf{1 . 9 5 6 . 4 4 5}$ \\
\hline
\end{tabular}

Sumber : UNCOMTRADE (2018)

sedangkan Jerman cukup mengalami peningkatan. Tahun 2015 nilai ekspor Inggris dengan USD 1.974.448, Belanda dengan USD 1.441.571 dan Italia dengan USD 897.196 berturut-turut menurun menjadi USD 1.620.532, USD 1.322.346 dan USD 782.673. Menurut Kemenperin (2016) nilai ekspor yang menurun disebabkan oleh persaingan yang cukup ketat dengan negara pengekspor furniture rotan lain yang semakin menggeliat seperti China dan Vietnam.

Selain itu, adanya krisis ekonomi global yang terjadi pada kurun 2013-2015 juga memberikan dampak pada penurunan nilai ekspor furniture rotan Indonesia. Masih adanya pihak-pihak terkait yang bermain pada ekspor bahan baku rotan mentah disinyalir juga sangat berdampak pada penurunan nilai ekspor furniture rotan Indonesia walaupun kebijakan pemerintah terkait pelarangannya telah dibuat, yakni melalui Peraturan Menteri Perdagangan Republik Indonesia, melalui SK No. 28/MDAG / PER / 10 / 2011 pada tanggal 30 November tahun 2011, terkait pelarangan ekspor bahan baku rotan mentah, rotan asalan, rotan W/S dan rotan setengah jadi. Dengan adanya berbagai kebijakan tersebut, bahan baku rotan yang ada secara penuh dapat dipergunakan oleh para pengusaha pengusaha di industri furniture rotan Indonesia.
Merujuk pada data yang ada, ekspor furniture rotan Indonesia semakin mengalami penurunan di tiap tahunnya dengan terus menunjukkan tren negatif. Hal tersebut sangat disayangkan karena pada dasarnya Indonesia memiliki keunggulan komparatif tersendiri yaitu dalam hal persediaan bahan baku untuk industri rotan, dan pusat produksi rotan mentah terbesar di dunia beradadi Indonesia. Kemunduran industri rotan yang terjadi Indonesia bisa jadi dikarenakan oleh berbagai macam hal, salah satunya terkait kebijakan ekspor bahan baku rotan dari pemerintah yang selalu berubahubah, dimana hal tersebut cukup menandakan masih belum terpenuhinya solusi kebijakan yang tepat dari pemerintah dalam memacu industri furniture rotan nasional. Tren negatif dari ekspor furniture rotan Indonesia tersebut masih berlangsung hingga sampai saat ini, dimana dampak dari terbukanya ekspor bahan baku rotan di tahun 2005 masih saja terbawa kepada para pengusaha bahan baku rotan di sektor hulu yang masih saja mengekspor bahan baku rotan secara ilegal, meskipun kebijakan pelarangan ekspor bahan baku rotan telah ditetapkan pada tahun 2011.

Implementasi kebijakan yang kurang efektif dari pemerintah tersebut lantas menimbulkan pertanyaan, telah sampai sejauh manakah daya saing ekspor furniture rotan kita saat ini, serta upaya seperti apa 
yang dapat dilakukan pemerintah untuk mendorong kembali peningkatan nilai ekspor rotan di Indonesia dan terus menumbuh kembangkan daya saingnya di tingkat internasional. Oleh karena itu perlu adanya suatu analisa untuk mengetahui besaran daya saing ekspor dari komoditas furniture rotan Indonesia tersebut mengingat dari tahun ke tahunnya nilai ekspor komoditas furniture rotan Indonesia semakin terus menurun.

\section{METODE}

Data yang dianalisis berupa nilai ekspor furniture rotan dengan kode HS 940381 di 4 negara eksportir eropa utama dari tahun 2007 sampai 2016. Rentang data tahun yang digunakan tersebut, merupakan data terakhir dari HS 940381 mengingat di tahun setelahnya komoditi HS 940381 telah berganti menjadi lebih spesifik lagi. Negara yang menjadi objek penelitian dipilih berdasarkan rata-rata nilai ekspor tertinggi selama 10 tahun terakhir dan berfokus di wilayah Eropa. Adapun negara eksportir Eropa utamanya yaitu Jerman, Belanda, Inggris, dan Italia. Metode kuantitatif yang digunakan adalah metode Revealed Comparative Advantages (RCA) yaitu untuk menganalisis daya saing furniture rotan Indonesia di negara tujuan ekspor dan Revealed Symetric Comparative Advantage (RSCA) untuk menganalisis dinamika perkembangan daya saing antar negara tujuan ekspor.

\section{REVEALED COMPARATIVE ADVANTAGE (RCA)}

RCA yang dikemukakan oleh Balassa (1965) merupakan salah satu alat ukur untuk menentukan tingkat kemampuan daya saing komoditas tertentu di pasar internasional. Rasio RCA ini akan digunakan dalam melakukan analisis perdagangan internasional untuk menentukan posisi ekspor produk tertentu suatu negara terhadap produk tertentu dari negara lainnya (Laursen 1998).
Menurut Basri dan Munandar (2010), RCA merupakan salah satu metode yang dinamis dan mampu digunakan untuk melakukan analsis daya saing. Penelitian ini menggunakan metode RCA untuk analisis daya saing seperti halnya digunakan pada beberapa penelitian komoditas perkebunan dan hasil hutan lainnya seperti teh (Suprihatini 2005), kopi (Boansi et al. 2013), kakao (Rifin 2013; Firdaus 2009), rotan (Hoang et al. 2017), manggis (Kustiari et al. 2012) dan kapas (Mohanty et al. 2003). Menurut Serin dan Civan (2008), RCA (Revealed Comparative Advantages) yang dikemukakan oleh Balassa (1965) merupakan salah satu alat ukur untuk menentukan tingkat kemampuan daya saing komoditas tertentu di pasar internasional. Rasio RCA ini akan digunakan dalam melakukan analisis perdagangan internasional untuk menentukan posisi ekspor produk tertentu suatu negara terhadap produk tertentu dari negara lainnya (Laursen 2015).

Secara matematis, RCA dapat dihitung menggunakan rumus seperti pada rumus (1) dimana variabel yang diukur pada metode ini meliputi kinerja ekspor suatu produk pada wilayah terhadap total ekspor wilayah tersebut yang kemudian dibandingkan dengan pangsa nilai produk dalam perdagangan dunia. Rumus dari RCA dapat dilihat pada persamaan berikut (Balassa dan Noland 1989):

$R C A i=\frac{X_{i j} / X_{i t}}{W_{i} / W_{t}}$

dimana:

RCAt : Nilai daya saing furniture rotan Indonesia ke tiap negara tujuan Eropa (Inggris, Jerman, Belanda \& Italia)

$X_{i j}$ : Nilai ekspor furniture rotan Indonesia ke tiap negara tujuan Eropa (Inggris, Jerman, Belanda \& Italia)

Xit : Nilai ekspor total semua komoditas Indonesia ke tiap negara tujuan Eropa (Inggris, Jerman, Belanda \& Italia)

$W_{\mathbf{i}}$ : Nilai ekspor furniture rotan seluruh Dunia ke tiap negara tujuan Eropa (Inggris, Jerman, Belanda \& Italia) 
$W_{\mathbf{t}} \quad$ : Nilai ekspor total semua komoditas Dunia ke tiap negara tujuan Eropa (Inggris, Jerman, Belanda \& Italia)

(Balassa 1965)

Dalam analisis yang lebih rinci, Indeks RCA Balassa dapat diklasifikasikan ke dalam empat tahap (Hinloopen 2001) :

1. Nilai $\mathrm{RCA}, 0<\mathrm{RCA}<1$, menunjukkan bahwa negara j tidak memiliki keunggulan komparatif (no competitiveness).

2. Nilai $R C A, 1<R C A<2$, menunjukkan bahwa negara $\mathrm{j}$ memiliki keunggulan komparatif akan tetapi masih lemah (week competitiveness).

3. Nilai RCA, $2<$ RCA $<4$, menunjukkan bahwa negara j memiliki keunggulan komparatif yang sedang (moderate competitiveness).

4. Nilai RCA $>4$, menunjukkan bahwa negara j memiliki keunggulan komparatif yang kuat (strong competitiveness).

\section{REVEALED SYMETRIC COMPARATIVE ADVANTAGE (RSCA)}

Penentuan tingkat daya saing menggunakan RCA juga memiliki kekurangan yang disebabkan karena hasil indeks yang tidak simetris (Laursen 1998).

Dalam penggunaannya, RCA juga tidak terlalu dapat menjelaskan apakah suatu pola perdagangan yang sedang terjadi sudah optimal atau belum. Penentuan tingkat daya saing menggunakan RCA juga memiliki kekurangan lain yakni hasil indeks yang diciptakan terkadang masih kurang simetris, dimana output yang dihasilkan analisis RCA tidak dapat dibandingkan pada kedua sisinya. Maka dilakukan modivikasi RCA atau indeks Balassa oleh Dalum dalam Oktaviani et al. (2014) yang dikenal dengan Revealed Symetric Comparative Advantage (RSCA). Range pengukuran RSCA berkisar antara -1 hingga 1 dan secara umum dirumuskan sebagai berikut:

$R S C A j=\frac{R C A_{t}-1}{R C A_{t}+1}$ dimana:

$\mathrm{RCA}_{\mathbf{t}}$ : Nilai daya saing furniture rotan Indonesia ke tiap negara tujuan Eropa (Inggris, Jerman, Belanda \& Italia)

RSCAj : Nilai RSCA suatu negara

t : 2007,..2016

(Dalum et al. 1998)

Dimana RSCAj, adalah RSCA ekspor komoditas furniture rotan Indonesia tiap negara importir eropa. Nilai RSCA berkisar antara -1 hingga 1 . Ketika nilai RSCA diatas nol (bernilai positif), artinya negara tersebut memiliki keunggulan komparatif untuk produk furniture rotan di negara tujuan utama. Sebaliknya jika RSCA bernilai negatif, maka negara tersebut tidak memiliki keunggulan komparatif komoditas furniture rotan.

\section{HASIL DAN PEMBAHASAN}

\section{ANALISIS DAYA SAING FURNITURE ROTAN INDONESIA DI NEGARA TUJUAN EROPA}

Perubahan keunggulan komparatif atau perubahan tingkat daya saing dapat dilihat dari nilai RCA yang dihasilkan. Apabila pangsa ekspor furniture rotan Indonesia di dalam total ekspor komoditi dari tiap negara tujuan lebih besar dibandingkan pangsa pasar ekspor komoditi furniture rotan dunia di dalam total ekspor komoditi di tiap negara tujuan tersebut, maka komoditi furniture rotan Indonesia tersebut dinilai memiliki keunggulan komparatif. Berdasarkan hasil analisis RCA yang telah dilakukan, dapat diketahui bahwa komoditi furniture rotan Indonesia memiliki keunggulan komparatif di pasar Jerman, Belanda, Inggris dan Italia dengan perolehan nilai rata-rata RCA yang kuat (RCA > 4) dan tergolong berdaya saing kuat (strong competitiveness) sesuai dengan penggolongan dari Hinloopen (2001).

Apabila diperhatikan pada Tabel 2, terlihat bahwa nilai RCA untuk komoditi furniture rotan Indonesia di Jerman, Belanda, Inggris dan Italia selama periode tahun 20072016 memiliki nilai di atas 4. Hal ini memiliki 
Tabel 2. Hasil Estimasi Daya Saing (RCA) Negara Importir Eropa Furniture Rotan (HS 940381) Indonesia Tahun 2007-2016

\begin{tabular}{crrrr}
\hline Tahun & UK & Jerman & Belanda & Italia \\
\hline 2007 & 204,33 & 170,39 & 113,23 & 168,04 \\
2008 & 207,50 & 141,69 & 81,55 & 33,37 \\
2009 & 114,07 & 110,91 & 55,54 & 36,12 \\
2010 & 182,74 & 202,40 & 83,00 & 123,47 \\
2011 & 186,40 & 182,52 & 40,45 & 108,56 \\
2012 & 118,97 & 61,20 & 43,81 & 104,78 \\
2013 & 117,09 & 40,82 & 60,52 & 146,12 \\
2014 & 88,46 & 45,55 & 59,36 & 128,03 \\
2015 & 114,95 & 23,22 & 38,38 & 109,62 \\
2016 & 75,57 & 20,61 & 27,56 & 51,38 \\
\hline Rata-rata & $\mathbf{1 4 1 , 0 1}$ & $\mathbf{9 9 , 9 3}$ & $\mathbf{6 0 , 3 4}$ & $\mathbf{1 0 0 , 9 5}$ \\
\hline
\end{tabular}

artian bahwa komoditas furniture rotan Indonesia mempunyai keunggulan komparatif di negara tujuan ekspor utama dibanding dengan daya saing untuk jenis komoditas yang sama. Terlihat dari nilai RCA pada Tabel 2. kekuatan daya saing industri furniture rotan Indonesia meskipun memiliki daya saing yang kuat akan tetapi mengalami pertumbuhan yang cukup fluktuatif dari tahun 2007-2016.

Terkait perkembangan daya saing di masing-masing negara tujuan, Inggris menjadi negara tujuan ekspor furniture rotan Indonesia dengan nilai daya saing tertinggi dan cukup mendominasi dibandingkan dengan negara lainnya, dimana di setiap tahunnya ekspor ke negara Inggris rata-rata memiliki nilai RCA sebesar 141,01 lalu disusul Italia dengan 100,95 kemudian Jerman dn Belanda masing-masing dengan 99,93, dan 60,34 . Inggris menjadi negara tujuan dengan nilai RCA terbesar dan cukup konsisten di setiap tahunnya dibandingkan dengan negara tujuan lainnya.

Periode nilai RCA terbesar dari Inggris terjadi di tahun 2007 dan 2008, dimana berturut-turut nilai RCA mampu menembus di angka 204,33 dan 207,50. Nilai tersebut merupakan nilai tertinggi juga untuk komoditas furniture rotan Indonesia di sepanjang periode di antara tiap negara tujuan. Peningkatan nilai RCA yang terjadi di tahun 2007-2008 tak berlaku di tahun berikutnya, dimana di tahun
2009 nilai RCA di Inggris justru menurun drastis dengan nilai 114,07 yang jauh dari angka sebelumnya yaitu 207,50. Penurunan drastis tersebut terjadi dikarenakan adanya krisis ekonomi dunia di tahun 2008-2009 yang berdampak pada penurunan daya beli masyarakat dunia termasuk untuk pasar furniture rotan Indonesia di negara Inggris. Kebijakan pemerintah Indonesia tentang komoditi rotan mentah yang tiap tahunnya berubah-ubah ditengarai ikut memperburuk nilai daya saing furniture rotan Indonesia. Banyaknya tuntutan dari pihak industri hulu membuat pemerintah mengeluarkan kebijakan pada pertengahan tahun 2005 melalui SK Menteri Perdagangan No.12/M-DAG/PER/6/2005 pada tanggal 30 Juni 2005 tentang ketentuan ekspor rotan yang di dalamnya juga berisikan kebijakan pencabutan larangan ekspor rotan.

Kebijakan pada tahun tersebut berakibat pada kurangnya bahan baku industri pengolahan furniture rotan lokal. Hal tersebut terjadi dikarenakan para pengusaha rotan mentah lebih tertarik menjual bahan baku rotan mentah tersebut ke luar negeri daripada ke pengusaha dalam negeri. Harga jual yang dipatok lebih tinggi menjadi salah satu alasan mereka tidak tertarik menjualnya ke pengusaha industri rotan dalam negeri. Dengan diberlakukannya kebijakan tersebut pasokan bahan baku industri furniture rotan Indonesia pun juga ikut berkurang, yang berakibat pada penurunan produksi furniture rotan Indonesia 
secara drastis dan hal tersebut sangat berpengaruh pada menurunnya daya saing industri furniture rotan. Tahun 2009 pemerintah kembali memperbaiki kebijakan tersebut dengan dikeluarkannya Peraturan Menteri Perdagangan Republik Indonesia No. 36/MDAG/PER/8/2009 yang menyatakan bahwa rotan asalan tidak boleh diekspor, dan rotan W/S dibatasi jumlah ekspornya sebesar 35.000 ton per tahun serta memiliki wajib pasok ke industri pengrajin rotan domestik. Akan tetapi tetap saja eksodus bahan baku rotan Indonesia secara besar-besaran ke luar negri tidak dapat dihindari meskipun pada saat itu beberapa kali masih dikenakan pajak ekspor.

Pemerintah kemudian mulai merespon perubahan yang terjadi, yakni dengan dikeluarkannya Peraturan Menteri Perdagangan Republik Indonesia, melalui SK No. 28/M-DAG/PER/10/2011 pada tanggal 30 November tahun 2011, terkait pelarangan ekspor bahan baku rotan mentah, rotan asalan, rotan W/S dan rotan setengah jadi. Dengan adanya berbagai kebijakan tersebut, bahan baku rotan yang ada secara penuh dapat dipergunakan oleh para pengusaha pengusaha di industri furniture rotan Indonesia. Hal tersebut berpengaruh positif pada peningkatan produksi dan nilai ekspor industri furniture rotan Indonesia, yang mana terlihat pada arus nilai RCA yang meningkat kembali di tahun 2010-2011 di hampir seluruh negara tujuan ekspor. Kestabilan nilai RCA tersebut menandakan adanya pengaruh tren positif daya saing industri furniture rotan Indonesia sejak diterapkannya peraturan pemerintah di tahun 2011.

Khusus untuk pasar Inggris, tahun 2010 nilai RCA mulai meningkat kembali dengan angka 182,74 dan terus membaik di angka 186,40 pada 2011. Meningkatnya nilai RCA di tahun tersebut memperlihatkan adanya perbaikan kebijakan yang telah diterapkan oleh pemerintah terkait pelarangan bahan baku rotan mentah, selain itu nilai RCA yang membaik juga disebabkan oleh adanya perbaikan dan perkembangan. Meskipun nilai RCA Inggris kembali menurun di periode setelahnya yaitu di tahun 2012 dengan nilai RCA sebesar 118,97 dan di 2013 dengan nilai 117,09. Tahun-tahun setelahnya nilai RCA mulai berkembang dan cenderung berangsur stabil meskipun masih cukup fluktuatif dari tahun ke tahun hingga 2016 akan tetapi tidak terjadi rentang penurunan yang drastis seperti yang pernah terjadi di 2009. Fluktuasi nilai RCA Inggris yang terjadi pada periode akhir tersebut menggambarkan ketatnya persaingan ekspor di pasar furniture rotan dunia yang datang dari para pesaing ekspor lain seperti China dan Vietnam. Selain itu fluktuasi yang terjadi disebabkan oleh adanya berbagai perubahan kebijakan Pemerintah Indonesia terkait pembatasan ekspor bahan baku rotan mentah yang masih berubah-ubah di tahun tersebut yang berakibat pada berbagai gejolak fluktuasi. Selain itu, adanya penerapan kebijakan tarif di Uni Eropa khususnya Inggris, terkait impor produk furniture di tahun 2008 dengan besaran 0,056\% juga menjadi faktor lain yang berdampak pada fluktuasi nilai yang ada.

Italia dan Jerman menjadi dua negara tujuan ekspor terbesar setelah Inggris, dimana nilai RCA di Italia per tahunnya menyentuh angka 100,95 dan Jerman di angka 99,93. Besaran nilai RCA tidak mengejutkan mengingat keduanya sama-sama menjadi negara importir furniture rotan yang cukup produktif setelah Inggris. Meskipun secara besaran impor furniture rotan dari Indonesia ke negara tujuan ekspor lainnya memiliki besaran nilai yang lebih besar, akan tetapi dari sisi nilai daya saing Italia dan Jerman lebih unggul. Hal itu tercermin dari besaran nilai pembaginya yaitu berupa besaran total nilai ekspor furniture rotan dunia terhadap negara tujuan dimana dalam hal ini besaran impor furniture rotan di Italia dan Jerman cenderung lebih didominasi oleh Indonesia dibandingkan dengan negara lainnya sehingga secara perhitungan daya saing meskipun nilai ekspor furniture rotan nya lebih rendah dibandingkan furniture rotan akan tetapi nilai daya saingnya lebih unggul. Selain itu fluktuasi yang terjadi pada nilai mata uang negara tujuan juga memiliki dampak yang 
cukup kuat, dimana Euro Italia dan Jerman jauh lebih stabil dibandingkan Dollar sekalipun di rentang periode tersebut cukup terus berfluktuasi.

Saat terjadi gejolak ekonomi yang berdampak pada fluktuasi mata uang negara tujuan, hal yang serupa secara tidak langsung juga berdampak pada nilai tukar Rupiah mengingat Indonesia menerapkan sistem kurs bebas. Sejak tahun 1997 hingga sekarang Indonesia menerapkan sistem kurs bebas dalam menetapkan nilai tukar Rupiah, dimana pada tahun sebelumnya, yaitu 19771997 Indonesia lebih menerapkan sistem kurs mengambang terkendali yang penetapan kursnya tidak sepenuhnya terjadi dari aktivitas pasar valuta dan masih ada campur tangan pemerintah untuk menetapkan nilai kurs maksimal dan minimal. Sedangkan, sistem kurs bebas yang ada saat ini lebih berbentuk suatu sistem ekonomi dimana kurs yang ada dibentuk oleh permintaan dan penawaran valuta asing di pasaran bebas dan lepas dari campur tangan pemerintah, sehingga segala hal yang terjadi di pasar bebas akan berdampak juga pada nilai tukar Rupiah. Dampak nilai mata uang tersebut juga langsung memiliki pengaruh dalam ranah daya saing mengingat nilai RCA yang ada dipengaruhi oleh nilai ekspor yang dihitung berdasarkan besaran nilai mata uang di tiap negara tujuan, sehingga menguat atau melemahnya nilai tukar Rupiah terhadap mata uang negara tujuan sangatlah penting pengaruhnya terhadap daya saing industry furniture rotan Indonesia.

Nilai RCA di Italia dan Jerman sendiri secara keseluruhan juga mengalami fluktuasi di sepanjang periode 2007-2016. Fluktuasi yang terjadi diantara dua pasar negara tujuan Uni Eropa tersebut terjadi lebih disebabkan oleh adanya penerapan kebijakan tarif di Uni Eropa terkait impor produk furniture yang mana salah satunya adalah produk mentah dan juga hasil jadi rotan di pada tahun 2008 dengan besaran 0,056\%. Tarif yang ada menjadi salah satu penghalang bagi para importir lokal disana untuk terus melakukan impor komoditi furniture rotan Indonesia dengan skala yang sama dari tahun sebelumnya. Adanya tarif tersebut menjadikan produk furniture rotan menjadi lebih mahal dari segi biaya yang berdampak pada lesunya minat konsumen yang ada disana, sehingga pasar ekspor menjadi tidak terlalu stabil. Selain itu fluktuasi yang terjadi juga dipengaruhi oleh kebijakan pemerintah Indonesia terkait buka tutupnya bahan baku rotan mentah yang masih sering berubah di periode tersebut yang menjadikan lesunya produksi di industri furniture rotan Indonesia. Hal yang unik adalah baik Italia maupun Jerman terlihat saling mengisi di sepanjang periode tersebut. Dalam periode awal di tahun 20072011 terlihat pangsa ekspor furniture rotan Indonesia di negara Jerman sangat tinggi dengan memperlihatkan besaran rata-rata nilai RCA yang cukup tinggi yakni diatas kisaran nilai 100 di periode tersebut. Tercatat terjadi peningkatan yang cukup tinggi juga dalam hal nilai RCA di periode tersebut yakni di tahun 2009 dengan nilai awal 110,91 meningkat drastis menjadi 202,40 di tahun 2010. Kemudian perlahan tapi pasti, besaran nilai RCA di negara Jerman mulai berangsur berubah drastis di periode tahun 2012-2016, yakni dengan nilai terendahnya sebesar 23,22 di tahun 2015 dan 20,61 di tahun 2016.

Besaran nilai RCA yang cukup tinggi di Jerman pada periode 2007-2011 lebih dikarenakan Indonesia sedang gencar-gencarnya berfokus pada produksi furniture rotannya. Selain itu, pada masa itu fokus ekspor furniture rotan Indonesia yang masih banyak berada di pangsa negara Jerman dan belum mulai beralih. Sedangkan pada periode setelahnya, pangsa ekspor yang tadinya berada penuh di Jerman mulai beralih ke pasar negara lain. Seakan menggambarkan hal tersebut, kelesuan yang terjadi di pasar Jerman di periode akhir yakni tahun 20122016 menjadikan produk furniture rotan Indonesia beralih dan diisi oleh pasar utama lain salah satunya adalah Italia. Berkebalikan dengan Jerman, Italia justru menunjukkan besaran nilai yang cukup tinggi di periode tersebut. Hal tersebut dapat terlihat dari besaran nilai RCA yang ada di Italia dalam 
periode yang sama yang semakin meningkat, dan tercatat terjadi lonjakan nilai RCA di dalam periode tersebut yakni di tahun 2012 dengan hanya 104,78 meningkat drastis menjadi 146,12 di tahun setelahnya. Peralihan nilai yang terjadi tersebut tidak menjadi suatu kebetulan semata, dimana dengan adanya produksi furniture rotan yang terus meningkat dari Indonesia pasti akan berdampak pada perluasan pasar lain selain negara sebelumnya, akan selalu muncul peminat baru dan pasar baru. Italia menjadi salah satu pasar yang tepat mengingat Italia sendiri merupakan negara dengan budaya dan nilai seni yang cukup tinggi sehingga memungkinkan disana untuk perkembangan seni furniture dan kerajinan rotan.

Selain Italia, Belanda juga menjadi salah satu negara Eropa yang secara tidak langsung menjadi opsi perpindahan pasar lain dimana terlihat dalam besaran nilai RCA yang terus meningkat di Belanda dalam periode 20112014 yakni dengan besaran nilai 40,45 di 2011 kemudian terus membaik di periode selanjutnya dengan nilai 43,81 dan mencapai puncak peningkatannya di 2013 sebesar 60,52, meskipun di periode setelahnya semakin menurun hingga di 2016. Penurunan di akhir periode hingga tahun 2016 tersebut secara tidak langsung juga memberikan gambaran bahwa setelah peralihan nilai ekspor RCA dari negara Jerman, nilai ekspor yang ada kemudian beralih ke pangsa yang lain lagi.

\section{DINAMIKA DAYA SAING FURNITURE ROTAN INDONESIA DI NEGARA TUJUAN EROPA}

Berdasarkan hasil analisis RSCA seperti yang terlihat pada Tabel 3. dapat diketahui bahwa komoditi furniture rotan Indonesia memiliki keunggulan komparatif di pasar Jerman, Belanda, Inggris dan Italia dengan perolehan nilai rata-rata Indeks RSCA diatas nol (bernilai positif) selama periode tahun 2007-2016. Tabel 3. menunjukkan perkembangan nilai RSCA furniture rotan Indonesia pada tahun 2007 hingga 2016, dimana alam perkembangannya nilai indeks RSCA furniture rotan Indonesia terus mengalami perkembangan yang cukup stabil dan konstan di tiap tahunnya. Hal tersebut terlihat dari nilai yang ada yakni hampir di setiap tahunnya nilai RSCA stabil dan konstan mendekati angka satu. Terkait perkembangannya, Inggris menjadi negara tujuan ekspor furniture rotan Indonesia dengan nilai RSCA yang paling stabil dibanding dengan negara lainnya, dimana di setiap tahunnya di negara Inggris rata-rata memiliki nilai RSCA sebesar 0,98. Hampir di setiap tahunnya Inggris menunjukkan kestabilan nilai tersebut, yakni tidak jauh dari kisaran 0,97 ke 0,99.

Kestabilan tersebut secara tidak langsung memperlihatkan bahwa pasar ekspor furniture rotan Indonesia di Inggris telah memiliki dominasi daya saing yang cukup kuat, dan konsisten terbukti dengan adanya permintaan

Tabel 3. Hasil Estimasi Dinamika Daya Saing (RSCA) Negara Importir Eropa Furniture Rotan (HS 940381) Indonesia Tahun 2007-2016

\begin{tabular}{ccccc}
\hline Tahun & UK & Jerman & Belanda & Italia \\
\hline 2007 & 0,99 & 0,99 & 0,98 & 0,99 \\
2008 & 0,99 & 0,99 & 0,98 & 0,94 \\
2009 & 0,98 & 0,98 & 0,96 & 0,95 \\
2010 & 0,99 & 0,99 & 0,98 & 0,98 \\
2011 & 0,99 & 0,99 & 0,95 & 0,98 \\
2012 & 0,98 & 0,97 & 0,96 & 0,98 \\
2013 & 0,98 & 0,95 & 0,97 & 0,99 \\
2014 & 0,98 & 0,96 & 0,97 & 0,98 \\
2015 & 0,98 & 0,92 & 0,95 & 0,98 \\
2016 & 0,97 & 0,91 & 0,93 & 0,96 \\
\hline Rata-rata & $\mathbf{0 , 9 8}$ & $\mathbf{0 , 9 6}$ & $\mathbf{0 , 9 6}$ & $\mathbf{0 , 9 7}$
\end{tabular}


furniture rotan Indonesia di negara tersebut yang tiap tahunnya cukup besar meskipun di eropa telah ditetapkan tarif impor untuk komoditi tersebut. Italia menjadi negara kedua terbaik dalam hal perkembangan nilai RSCA, dimana secara garis besar nilai yang ada di italia dalam periode 2007-2016 cukup berkembang dan stabil seperti di negara Inggris. Hal yang cukup membedakan adalah di periode awal justru nilai RSCA di Italia sangat drastis menurun, yakni terjadi di periode 2008 dengan hanya 0,94 yang menurun dari nilai sebelumnya 0,99 .

Kinerja daya saing furniture rotan Indonesia di Italia kembali membaik di tahun 2009, dimana hal tersebut ditunjukkan dengan meningkatnya nilai RSCA yang ada menjadi 0,95 di 2009 kemudian terus membaik di periode selanjutnya dengan nilai 0,98 dan mencapai puncaknya di 2013 sebesar 0,99. Setelah itu besaran nilai RSCA yang ada di Italia lebih cenderung stabil dan bersaing dengan besaran yang mirip dengan negara Inggris. Kestabilan nilai yang ada di Inggris dan Italia menjadi salah satu bentuk gambaran pasti dalam pemetaan daya saing di pasar komoditi furniture rotan Indonesia. Tren kestabilan ini seharusnya dapat menjadi acuan tersendiri bagi Indonesia untuk lebih memberikan prioritas bagi perkembangan ekspor furniture rotan ke negara tersebut guna menunjang perkembangan daya saing furniture rotan di masa mendatang.

Berbeda halnya dengan Inggris dan Italia, Jerman pada awalnya terlihat menunjukkan perkembangan yang stabil dan hampir mirip dengan Inggris, akan tetapi di periode 2012 Jerman mulai menunjukkan tren buruk nilai RSCA nya dan semakin drastis di 2013, kemudian meningkat kembali di 2014 sebelum akhirnya menukik drastis lagi di 2015 dan 2016. Penurunan nilai RSCA Jerman di 2015 bahkan menjadi penurunan nilai RSCA terbesar di periode tersebut di bandingkan dengan nilai RSCA yang ada di negara lain. Hal yang tak jauh berbeda terjadi juga dengan perkembangan nilai Belanda, dimana Belanda tercatat memiliki nilai RSCA dengan gambaran yang kurang stabil dan cenderung cukup fluktuatif. Dalam rentang periode 20072016 fluktuasi yang terjadi di Belanda cukup terlihat dari besarnya nilai RSCA yang berubah-ubah, contoh saja terjadinya penurunan nilai di tahun 2007-2009 yakni yang sebelumnya memiliki besaran nilai awal RSCA di angka 0,98 menurun menjadin 0,96 di 2009.

Pada periode setelahnya, kenaikan drastis justru terjadi di negara tersebut dan mencapai puncak tertingginya di tahun 2010 dengan nilai RSCA Belanda sebesar 0,98. Fluktuasi nilai RSCA yang ada secara garis besar memang mayoritas terjadi di negaranegara tujuan di Eropa dan tak berbeda jauh bedanya dengan fluktuasi yang terjadi pada nilai RCA. Hal tersebut cukup menunjukkan ketidakkonsistenan dari kinerja ekspor dan juga daya saing dari komoditi furniture rotan Indonesia yang memang dipengaruhi oleh adanya penerapan kebijakan tarif di Uni Eropa terkait impor produk furniture yang mana salah satunya adalah tarif produk mentah dan juga hasil jadi rotan di pada tahun 2008 dengan besaran 0,056\% (UNCTAD 2018). Selain dikarenakan tarif impor tersebut, krisis ekonomi dunia di periode tahun 2008-2010 juga menjadi salah satu faktor yang menyebabkan fluktuasi nilai tersebut. Nilai tukar Rupiah yang terpengaruh oleh mata uang asing negara ekspor selalu berubah dari waktu ke waktu dan cukup memberi dampak pada setiap perubahan yang terjadi. Perubahan nilai mata uang tersebut berhubungan dengan keputusan pelaku kegiatan perdagangan.

Peningkatan maupun penurunan kurs mata uang sangat mempengaruhi keputusan pelaku eskpor furniture rotan Indonesia untuk menjual produknya. Perbedaan nilai tukar mata uang suatu negara pada prinsipnya ditentukan oleh besarnya permintaan dan penawaran mata uang tersebut. Kurs merupakan salah satu harga yang penting dalam perekonomian terbuka karena ditentukan oleh adanya keseimbangan permintaan dan penawaran yang terjadi di pasar. Kurs juga dapat dijadikan alat ukur untuk mengukur kondisi perekonomian suatu negara. Pertumbuhan nilai mata uang yang stabil menunjuk- 
kan perekonomian suatu negara memiliki kondisi ekonomi yang relatif baik. Melemahnya nilai tukar Rupiah menyebabkan perekonomian Indonesia menjadi tidak stabil dan dilanda krisis ekonomi serta kepercayaan terhadap mata uang dalam negeri menurun. Ketika krisis terjadi, ekonomi Indonesia akan terpengaruhi. Hal tersebut langsung berdampak pada pelemahan mata uang Rupiah terhadap nilai tukar mata uang asing negara ekspor dan menyebabkan ketidakstabilan pada nilai tersebut. Tidak stabilnya nilai kurs Rupiah terhadap nilai tukar mata uang asing negara tujuan menyebabkan nilai ekspor furniture rotan Indonesia turut berfluktuasi sehingga mempengaruhi kinerja ekspor dan daya saing furniture rotan Indonesia itu sendiri.

\section{KESIMPULAN DAN SARAN}

\section{KESIMPULAN}

Hasil penelitian menunjukkan bahwa dalam kurun waktu 2007-2016, Melalui pendekatan RCA maupun RSCA, furniture rotan Indonesia memiliki besaran nilai yang tergolong berdaya saing kuat dalam hal komoditas furniture rotan di negara tujuan Eropa. Nilai RCA menunjukkan keunggulan komparatif ekspor furniture rotan Indonesia di masing-masing negara importir, dimana negara tujuan dengan besaran keunggulan komparatif tertinggi berada di pangsa Inggris diikuti dengan Italia dan Jerman menjadi negara setelahnya yang memiliki besaran yang cukup sama, sedangkan Belanda berada di urutan trakhir. Berdasarkan nilai RSCA juga diperoleh kesimpulan yang cukup sama, dimana nilai RSCA Indonesia untuk pasar furniture rotan di pasar negara Inggris merupakan nilai RSCA yang paling mendekati 1 jika dibandingkan dengan negara tujuan lainnya. Negara tujuan Inggris secara garis besar memiliki nilai rata-rata RCA dan RSCA yang mengindikasikan posisi daya saing yang paling kuat diantara keempat negara eksportir utama, namun jika diperhatikan lebih lanjut, selain pasar utama Inggris, posisi daya saing yang kuat juga dimiliki oleh Italia dan Jerman yang menjadikan keduanya sebagai pasar ekspor lainnya yang dapat dijadikan opsi utama pangsa ekspor lain dalam hal ekspor furniture rotan Indonesia.

\section{SARAN}

Pengembangan daya saing furniture rotan Indonesia melalui perluasan pangsa pasar menjadi suatu keharusan bagi komoditi ini di masa mendatang. Terkait pangsa pasar di negara tujuan, Indonesia diharapkan dapat lebih meningkatkan perdagangannya ke pasar negara Inggris, Italia, dan juga Jerman, dimana di ketiga negara tersebut memiliki nilai daya saing yang bagus dan tergolong kuat, serta memiliki potensi yang sangat baik untuk dilakukan ekspansi perdagangan di masa yang akan datang. Kekonsistenan dari Pemerintah dalam menerapkan pembatasan ekspor bahan baku sangatlah diperlukan, hal tersebut dapat dilakukan melalui suatu skema pengawasan. Adanya suatu badan penyangga diharapkan dapat berfungsi sebagai stabilisator ketersediaan bahan baku bagi industri furniture rotan di Indonesia baik dari segi kuantitas, kualitas maupun harga.

\section{DAFTAR PUSTAKA}

Balassa B. 1965. Trade liberalization and revealed comparative advantage. The Manchester School of Economic and Social Studies. 33: 92-123.

Balassa B, Noland M. 1989. Revealed Comparative Advantage in Japan and the United States. Journal of International Economic Integration. 4(2): 8-22.

Basri F, Haris M. 2010. Dasar-Dasar Ekonomi Internasional: Pengenalan \& Aplikasi Metode Kuantitatif. Jakarta (ID): Kencana.

Boansi, David dan Crentsil, Christian. 2013. Competitiveness and Determinants of Coffee Exports, Producer Price and Production for Ethiopia. Journal of Advanced Research in Economics and International Business Vol. 1, Issue 1(1) 
Boansi D, Odilon K, Lokonon B, Appah J. 2014. Determinants of agricultural export trade: a case of fresh pineapple exports from Ghana. British journal of economics, management \& trade. 4(11):1736-1754.

Firdaus M. 2007. Analisis Daya Saing Kedelai di Jawa Timur. J-SEP. 1 (2): 16-27.

Firdaus M, Ariyoso. 2009. Keterpaduan Pasar dan Faktor-faktor yang Mempengaruhi Harga Kakao Indonesia. Jurnal Ekonomi dan Kebijakan Pembangunan, 3(1): 69-79.

Gujarati D. 2006. Dasar-Dasar Ekonometrika. Mulyadi, J, A; Penerjemah; Saat, S; Hardani, W; Editor. Jakarta (ID): Erlangga. Terjemahan dari: Essentials of Economics.

Hinloopen J. 2001. On the empirical distribution of the Balassa Index. Review of World Economics. 137 (1): 1-49.

Hoang V, Tran T, Tu V, Nguyen N, Nguyen Q. 2017. Agricultural Competitiveness of Vietnam by the RCA and the NRCA Indices, and Consistency of Competitiveness Indice. AGRIS on-line Papers in Economics and Informatics. 9 (4): 53-67.

[KEMENPERIN] Kementerian Perindustrian. 2017. Perkembangan Ekspor Indonesia Berdasarkan Sektor. Jakarta (ID): Kementerian Perindustrian Republik Indonesia.

Kismandani A. 2008. Daya Saing Furnitur Rotan Indonesia di Pasar Internasional dan Strategi Pengembangannya. Jurnal Kebijakan Ekonomi. 4 (1): 17-37.

Kustiari R., Purba H, Hermanto. 2012. Analisis Daya Saing Manggis Indonesia di Pasar Dunia (Studi Kasus di Sumatera Barat). Jurnal Agro Ekonomi. 30 (1): 81-107.

Laursen K. 2015. Revealed comparative advantage and the alternatives as measures of international specialization. Eurasia Business and Economics Society. 5: 99-115.
Mohanty S, Fang C, Chaudhary J. (2003). Assessing the Competitiveness of Indian Cotton Production: A Policy Analysis Matrix Approach, Journal of Cotton Science. 7(3).

Oktaviani R, Novianti T. 2014. Teori Perdagangan Internasional; Aplikasinya di Indonesia. Bogor (ID): IPB Press.

Rifin, A. 2013. Competitiveness of Indonesia's Cocoa Beans Export in the World Market. IJTEF 2013.4 (1): $301 . \quad$ DOI: 10.7763/IJTEF.2013

Seyoum B. 2007. "Revealed comparative advantage and competitiveness in services: A study with special emphasis on developing countries". Journal of Economic Studies. Vol. 34 Iss. 5: 376 - 388

Serin V dan Civan A. 2008. Revealed Comparative Advantage and Competitiveness: A Case Study for Turkey Towards the EU. Journal of Economics and Social Research 10(2): 25-41.

Suprihatini, R. 2005. Daya Saing Ekspor The Indonesia di Pasar Dunia. Jurnal Agro Ekonomi, Vol. 23 No. 1: 1-29.

UNCTAD. 2018. Tariff Measures to Trade: Economic and Policy Issues for Developing Countries. Switzerland. Geneva.

World Bank. 2018. Pink sheet data World Bank. Washington DC: World Bank. 